\title{
STEM Career Preferences of the Anatolian High School Students from Different Socioeconomic Levels
}

\author{
Esra Kizılay (Corresponding author) \\ Erciyes University, Turkey \\ E-mail: eguven@erciyes.edu.tr
}

Havva Yamak

Gazi University, Turkey

E-mail: havva@gazi.edu.tr

Nusret Kavak

Gazi University, Turkey

E-mail:nkavak@gazi.edu.tr

Received: July 10, 2019 Accepted: August 25, 2019 Published: August 29, 2019

doi:10.5296/jei.v5i2.15069 URL: https://doi.org/10.5296/jei.v5i2.15069

\begin{abstract}
The purpose of this study is to reveal the science, technology, engineering and mathematics (STEM) career preferences in university of the students at different socioeconomic levels studying in Anatolian high schools and the relation between their socioeconomic levels and preferences. The research is performed with 886 students studying in Anatolian high schools in Kayseri province in the second term of the 2016-2017 academic year. The data is gathered via a form with demographic information and university career preferences of the students. The socioeconomic levels of the students are determined and their university career preferences are coded as STEM career field or non-STEM career field. In the analysis of the data, the SPSS 22 program is utilized. In the analysis of the data, frequency, percentage, and chi-square analysis are used. In the research, a significant relation is found between the socioeconomic levels of the students and whether their university career preferences are within the STEM field or not.
\end{abstract}


Keywords: STEM majors, Socioeconomic level, STEM career, High school, Career preference

\section{Introduction}

The stages of industrialization, which have continued until today, have finally been named as Industry 4.0. Industry 4.0 refers to the situation that occurs as a result of the developments such as communication, internet and technology (Eldem, 2017). Industry 4.0 has four main benefits. These productivity, revenue growth, and employment and investment. In terms of employment, it is thought that there will be an increase in the need for employment through industry 4.0. It is expected that new employment demands will be more relevant to individuals using technology (especially in the areas of mechanical-engineering). In addition, the demand for qualified and well-trained staff with different skills is expected to increase. Education is therefore very important for industry 4.0. It is very important to keep up with the technological innovations brought by Industry 4.0, to provide qualified labor force that can provide production, to train engineers and to update the curricula in parallel with these (EBSO, 2015; MESS, 2017).

The increasing information and the subsequent technological advancements today, require some properties for the individuals to follow the developments and to keep up with the contemporary (Akgunduz, 2016; Beers, n.d.). These properties that the individuals should carry are called the 21 st century skills. Creativity, problem solving, critical thinking, communication, innovation, career, scientific literacy and similar skills reside within the $21 \mathrm{st}$ century skills (ATC21S, n.d.; Griffin \& Care, 2015; MEB EARGED, 2011; NCREL \& Metiri Group, 2003; P21, 2016; World Economic Forum, 2015). The changes in the contemporary world caused or still causing changes in the occupation groups in parallel with the $21 \mathrm{st}$ century skills. Occupations like aerospace engineering, brain signal decoder, augmented reality architecture, robotics consultancy, synthetic life engineering, programming and software development have emerged and more are seen as probable to emerge (Bakhshi, Downing, Osborne, \& Schneider, 2017; Frey, 2011; Talwar \& Hancock, 2010; UKCES, 2014; Wagner, 2011).

When the 21 st century skills and the occupations of the future are considered, it is seen that in fact our age requires science, technology, engineering and mathematics (STEM) professionals. Because so-called occupations of future contains interdisciplinary collaboration covering science, technology, engineering and mathematics. This shows also that most of the occupations of future shall be assessed under STEM careers. Also, the STEM occupations and professionals require the 21 st century skills. Accordingly, in order for the countries to keep up with the requirements of the modernity and develop economically, it is possible to say that one of the most important elements is the STEM professionals (Carnevale, Smith, \& Melton, n.d.). Thus, countries care for the STEM careers and the labor force working in these fields to be able to keep up with the contemporary world and to compete. For example, countries at the top economically like United State achieve their economic success with their investments in STEM fields (Aydeniz, 2017). Therefore, countries have initiated plans regarding the STEM education and careers. In a report on STEM education, it is stated that 
most of 30 countries define the STEM education as a national priority. However, in most of the countries, it is indicated that STEM career consultancy issues have less of a position (Kearney, 2016). When the activities of the countries regarding STEM careers are considered, in a high school in California state in United States, STEM oriented career and technical education is provided (National Research Council, 2011). In United Kingdom (UK) there is a Science, Technology, Engineering and Mathematics Career Action Program. This program is designed to support the career labor force for students between 11 and 16 years of age (European Commission/EACEA/Eurydice, 2011). Another activity in UK, STEMNET aims to inform the youth in STEM career opportunities (STEM Learning, n.d.). Netherlands has developed a STEM education strategy. This strategy is created to cope with the insufficiency of scientists and engineers in the country (Kearney, 2016). With the "Lily" project started in Norway, it is aimed to encourage and contribute to the youth for the STEM careers (Naturfagsenteret, 2017). In Turkey, there are also some activities regarding STEM education and careers.

In our country, whereas there is no special state strategy developed regarding to the STEM education by the Ministry of National Education (MEB), there are some activities conducted (Kearney, 2016). The first studies on STEM have been implemented in Kayseri (Kayseri Il Milli Egitim Mudurlugu, 2013). In a report issued by TÜBİTAK in 2010, it is seen that some strategies are related to STEM education (TUBITAK, 2010). In 2014 "STEM Summit" is held (TUSIAD, 2014). The "STEM Education Report" is issued by MEB in 2016 (MEB, 2016). In the science course curriculum issued in 2018, some STEM education emphases are present (MEB, 2018). There are STEM studies in some universities of Turkey. In 10 education faculties there are policies regarding STEM education (Colakoglu \& Gunay Gokben, 2017). Despite all these activities, the number of STEM professionals and students preferring STEM careers in our country is still very low. When the occupation distribution is considered, it can be seen that the number of professionals is significantly low in STEM occupations like physics, mathematics, engineering (Ercan, 2011; ISKUR, 2017a; ISKUR, 2017b). There are also similar results among the students starting their university career trainings. It can be said that the number of the students preferring to pursue careers in majors like statistics, science, mathematics, and engineering is low (OECD, 2017; YOK, 2017). Therefore, it shall be accurate to research the issue of the preference and reasons of STEM careers in our countries to direct the activities to be performed accordingly.

Even though there are studies related to careers in previous years in our country, the research on STEM careers are started to be done in recent years. It is seen that in previous years some studies are performed in career preferences of the students (Akbayir, 2002; Batur \& Adiguzel, 2014; Genc, Kaya, \& Genc, 2007; Hamamci, Bacanli, \& Dogan, 2013; Kaya, Aslan, \& Gunal, 2013; Korkut-Owen, Kepir, Ozdemir, Ulas, \& Yilmaz, 2012; G. Ozsoy, S. Ozsoy, Ozkara, \& Memis, 2010; Sarikaya \& Khorshid, 2009) and generally the reasons of preferences of the students are examined. Looking at these studies, it can be said that studies are more focused on the university students. However, performing the studies that shall guide the activities related to the careers of the students at high school level shall provide guidance both for consultancy activities in high schools and for the state policies. In the related literature in our 


\section{Macrothink}

country, in recent years, there are also studies related to the STEM careers (Korkut-Owen \& Mutlu, 2016; Korkut Owen \& Eraslan Capan, 2017, 2018; Koyunlu Unlu, Dokme, \& Unlu, 2016; Yerdelen, Kahraman, \& Tas, 2016). Looking at these research, it can be seen that there is a need for studies in the related literature on STEM careers in our country. With this study performed, it is aimed to examine the STEM career preferences of the Anatolian high school students and their relationship with these preferences and socioeconomic level.

\section{Methodology}

\subsection{Research Design}

This research is realized via cross sectional descriptive research among quantitative research patterns. In descriptive research the notions continue to exist are explained via description. In cross sectional descriptive research, whereas, not the entire universe is taken handled while explaining these notions, but groups that shall represent it are studied. In short, in cross sectional descriptive research can be said to be used in defining the status of the data that partly exists in a short period of time (Johnson \& Christensen, 2014; Sonmez \& Alacapinar, 2011). In this research as the STEM career preferences of the students in Kayseri province public Anatolian high schools are examined, the descriptive research pattern is used. As it is very hard to reach the entire universe a sample representing it is studied on, thus cross sectional descriptive research among descriptive research patterns is preferred.

\subsection{Universe and Sample}

In the research, students in public Anatolian high schools within Kayseri province in Turkey were chosen as the universe. Looking at report issued by the Kayseri Province National Education Directorate (Kayseri Il Milli Egitim Mudurlugu, 2016), it was seen that the number of students in public Anatolian high schools is 24684. In defining the sample number in this universe, the formula suggested by Cochran (1962; as cited in Balci, 2011) was used. According to this formula, the size of the sample to be selected at $95 \%$ confidence level and 0.05 tolerance level is determined to be approximately 380 persons. In this research, 886 high school students selected from the universe were the sample of the research.

The demographical properties of the students in the sample of the research were given in the Table 1. 
Table 1. The demographical properties of the students in the sample of the research

\begin{tabular}{|l|l|l|l|}
\hline Demographical properties & Number of Students (N) & Percentage of Students (\%) \\
\hline \multirow{4}{*}{ Gender } & Male & 353 & 39.8 \\
\cline { 2 - 4 } & Female & 533 & 60.2 \\
\hline \multirow{4}{*}{ Class level } & 9 & 249 & 28.1 \\
\cline { 2 - 4 } & 10 & 251 & 28.3 \\
\cline { 2 - 4 } & 11 & 271 & 30.6 \\
\cline { 2 - 4 } & 12 & 115 & 13.0 \\
\hline Total & & 886 & 100 \\
\hline
\end{tabular}

When Table 1 was examined, it is seen that $39.8 \%$ of the 886 public Anatolian high school students in the research are male and $60.2 \%$ are female. When the class levels of the students in the research were examined it is seen that the number of students participating in the research from 12th class is lower than the other class levels. It was determined that the numbers of the participation to the research from other class levels are close to each other.

\subsection{Data Collection Tool and Data Analysis}

In the research, information on the gender, class levels, education levels of mother and father, number of people in the family and the monthly total income of the family of the students were gathered. Also, it was requested from the students to write their university career preferences.

Research data were gathered from the Kayseri province public Anatolian high schools in the second term of the 2016-2017 academic year. Before the data were gathered, the necessary permits are taken from the Kayseri Province National Education Directorate and the Kayseri Governorship.

Before the analysis of the data, it was determined whether the university career preferences of the students are within STEM fields or not. For this purpose, the detailed STEM undergraduate majors table in the report prepared by Noonan (2017) is used. According to this report STEM undergraduate majors are divided into four in general. These are computer majors, mathematics majors, engineering majors, and physical and life sciences majors. The physical and life sciences majors consist of majors like astronomy, chemistry, biology, physiology, earth sciences, physics, pharmacology (Noonan, 2017). According to this classification the university career preferences of the students in the research were coded as STEM related and non-STEM related fields. In the analysis of the data SPSS 22 program was utilized. In the analysis of the data frequency, percentage, and chi square analysis were used.

\section{Findings}

\subsection{Classification of the Student According to Their Socioeconomic Levels}

In the research, primarily, it was needed to determine the socioeconomic levels of the 


\section{Al Macrothink}

Anatolian high school students participated in the research. In order to classify the students according to their socioeconomic levels many properties are needed to be considered. The properties like the level of education of mother and father, the income of the family, the number of people in the family of the students have a role in determining the socioeconomic level. In many researches (Bursal, Buldur, \& Dede, 2015; Erkan, 2011; Kapucu \& Bahcivan, 2016; Uzun \& Saglam, 2005) the socioeconomic levels are determined taking these properties into account.

In order to separate as low, mid and upper socioeconomic levels according to the monthly income of the families of the students, first of all the data on year 2016 in the Turkey income distribution and living conditions statistics were examined. According to these data, the annual income of \%25 group of the household with dependent child in 2016 is 22598 TL. $50 \%$ group of the same has 34000 TL annual income. 75\% group has 51455 TL annual income (TUIK, 2016). When these incomes are calculated monthly they are 1883 TL, 2833 TL and $4288 \mathrm{TL}$ respectively. Thus when we take $25 \%$ group as the low socioeconomic group the monthly income of the family is $1883 \mathrm{TL}$ in average, for $50 \%$ mid socioeconomic group monthly income is $2833 \mathrm{TL}$ and for $75 \%$ upper socioeconomic group the monthly income is $4288 \mathrm{TL}$.

Considering the values given above, in this research, the students with familial monthly income less than $2000 \mathrm{TL}$ are classified in low socioeconomic level, ones with 2001-4000 TL in mid socioeconomic level and ones with over 4000 TL in upper socioeconomic level.

The classification of the students in the research according to their socioeconomic levels is given in Table 2.

Table 2. The classification of the students in the research according to their socioeconomic levels

\begin{tabular}{|l|l|l|l|}
\hline Monthly income of family & Socioeconomic level & Number of Students (N) & Percentage of Students (\%) \\
\hline Less than 2000 TL & Low & 239 & 27 \\
\hline Between 2001-4000 TL & Mid & 425 & 48 \\
\hline More than 4000 TL & Upper & 222 & 25 \\
\hline Total & & 886 & 100 \\
\hline
\end{tabular}

When Table 2 is examined it is seen that $27 \%$ of the Anatolian high school students participated in the research are in low socioeconomic level, $48 \%$ are in mid socioeconomic level and 25\% are in upper socioeconomic level.

\subsection{University Career Preferences and STEM Career Preferences of the Students}

The university career preferences and STEM career preferences of the students participated in the research are given in Table 3. Many fields names are given by the students for the 
university career preferences. Thus majors names with high frequency are given.

Table 3. University career preferences of the students

\begin{tabular}{|l|l|l|l|}
\hline Fields & Frequency & Percentage & STEM career field \\
\hline Medicine & 222 & 25.1 & + \\
\hline Engineering & 116 & 13.1 & + \\
\hline Law & 87 & 9.8 & - \\
\hline Architecture & 56 & 6.3 & + \\
\hline PDR & 30 & 3.4 & - \\
\hline Police Force & 30 & 3.4 & - \\
\hline
\end{tabular}

When Table 3 is examined, it can be seen that many of the students prefer to have a career in medicine that is one of the STEM career fields (25.1\%). The second most preferred fields by the students, engineering, is also within the STEM career fields $(13.1 \%)$. The number of students wishing to have a career in Law field, a non-STEM career field, is at the third place in total $(9.8 \%)$.

The STEM undergraduate majors preferences of the students participated in the research are given in Table 4.

When Table 4 is examined, it can be seen that many of the students prefer to have a career in STEM career majors (58.2\%). Many of students prefer to have a career physical and life sciences majors that is one of the STEM career majors (33.9\%). The second most preferred majors by the students, engineering majors, is also within the STEM career majors $(21.2 \%)$. The number of students wishing to have a career in mathematics majors is at the third place in STEM career majors (2.4\%).

Table 4. STEM undergraduate majors preferences of the students

\begin{tabular}{|l|l|l|}
\hline Majors & Frequency & Percentage \\
\hline Computer majors & 7 & 0.8 \\
\hline Mathematics majors & 21 & 2.4 \\
\hline Engineering majors & 188 & 21.2 \\
\hline Physical and life sciences majors & 300 & 33.9 \\
\hline Non-STEM majors & 370 & 41.8 \\
\hline
\end{tabular}




\subsection{STEM Career Preferences of the Students According to the Socioeconomic Level}

The results regarding whether the STEM career preferences in university of the Anatolian high school students show difference according to the socioeconomic level are achieved by chi-square analysis. The results are given in Table 5.

When Table 5 is examined, it is seen that $58.2 \%$ of Anatolian high school the students participated in the research make a STEM career preference in university. When the STEM career preferences of the students according to their socioeconomic levels, it is seen that there is great difference between the percentages of the students in low and upper socioeconomic levels. $54.4 \%$ of the Anatolian high school students in low socioeconomic level prefer STEM careers in university, while $70.7 \%$ of students in upper socioeconomic level prefer STEM careers in university. It is seen that the percentages of students preferring STEM careers in the low and mid socioeconomic levels are close. In the research, it was found that the differences between the STEM career preferences of the Anatolian high school students according to their socioeconomic levels are significant $\left[\chi^{2}(s d=2, n=886)=18.991 ; p<.05\right]$. According to this result, it can be said that there is a significant relation between the university STEM career preferences and the socioeconomic levels of the students.

Table 5. STEM career preferences in university of the students according to socioeconomic levels

\begin{tabular}{|c|c|c|c|c|c|}
\hline & & & STEM career field & Non-STEM career field & Total \\
\hline \multirow{6}{*}{ Socioeconomic level } & \multirow{2}{*}{ Low } & $\mathrm{N}$ & 130 & 109 & 239 \\
\hline & & $\%$ & 54.4 & 45.6 & 100 \\
\hline & \multirow{2}{*}{ Mid } & $\mathrm{N}$ & 229 & 196 & 425 \\
\hline & & $\%$ & 53.9 & 46.1 & 100 \\
\hline & \multirow{2}{*}{ Upper } & $\mathrm{N}$ & 157 & 65 & 222 \\
\hline & & $\%$ & 70.7 & 29.3 & 100 \\
\hline \multirow{2}{*}{\multicolumn{2}{|c|}{ Total }} & $\mathrm{N}$ & 516 & 370 & 886 \\
\hline & & $\%$ & 58.2 & 41.8 & 100 \\
\hline
\end{tabular}

Note. $\chi^{2}=18.991 ; \mathrm{sd}=2 ; \mathrm{p}=.000$.

\section{Discussion and Recommendations}

In the research, the relation between the university STEM career preferences and the socioeconomic levels of the Anatolian high school students is examined. It is seen that $58.2 \%$ of Anatolian high school the students participated in the research make a STEM career preference in university. Many of students prefer to have a career in the physical and life sciences majors (33.9\%). The second most preferred majors by the students, engineering majors, is also within the STEM career majors (21.2\%). Yerdelen et al. (2016) have 
determined in their study that more than half of the secondary school students' career plans contain STEM fields. A similar result is also achieved in a research conducted by Gulhan and Sahin (2018). In the research, it is determined that the ratio of secondary school $5^{\text {th }}$ class students that do not prefer any STEM occupation is low.

When the career preferences in university of the students is examined in the research, it is determined that most of the students $(25.1 \%)$ prefer to make a career in the field of medicine. The second place in career preferences of the students is engineering field (13.1\%) and the third place is the law field $(9.8 \%)$.

In a research conducted by Karakus Kacmaz (2014) the occupational preferences of the individuals at the stage of university preference are also examined. In the research the occupations the individuals desire are determined, in order, as physician, teacher, engineering and law.

Altay Kose and Yangin (2015), in their research, showed that the primary and secondary school students interest more the career fields like medicine.

In a study conducted by Cakirer Calbayram and Gonenc (2017), it is determined that of the high school senior class students $36.7 \%$ wishes to be engineer, $10.4 \%$ doctor, $9.9 \%$ lawyer.

In the research performed by Eraslan Capan and Korkut Owen (2017), it is seen that the high school students think to prefer engineering, production and construction fields more. This is followed by health and social services fields.

In order to examine the relation between the career preferences and the socioeconomic levels of the students participating in the research, first of all the students are classified according to their socioeconomic levels. It is seen that the $27 \%$ of the students are in the low socioeconomic level, $48 \%$ in the mid socioeconomic level and $25 \%$ in the upper socioeconomic level. When the STEM career preferences of the students according to the socioeconomic levels are examined, it is determined that the percentage of STEM career preferences of the students in low and mid socioeconomic levels are close to each other. However, it is determined that there is a difference between the STEM career preference ratios of the students in low and upper socioeconomic levels. While $54.4 \%$ of the students in low socioeconomic level prefer STEM careers in university, $70.7 \%$ of students in upper socioeconomic level prefer STEM careers in university. This result shows that there is a significant relation between the university STEM career preferences and the socioeconomic levels of the students. Also in a study performed by Bahar (2002), a significant relation between the monthly income average of the families of the university students studying in some majors and the career field they have chosen. Ozer and Calmasur (2012), in their research, have examined the faculty preference reasons of the university students. In the research it is determined that among the factors affecting the faculty preferences of the students there is also the income of the mother and father. Koksal (2016), in a study, examined the factors affecting the occupation preferences of the university students. As the result of examination, there is a significant difference detected according to the familial income in the skill and occupation dimension of the students. In the study of Yerdelen et al. 
(2016) it is determined that the STEM career interest of the students in low socioeconomic status is over $50 \%$.

As a result, in this research there is a significant relation found in between the socioeconomic levels and the university STEM career preferences of the Anatolian high school students. It is determined that the STEM career preference ratios of the students from the low socioeconomic level are low. Because the students in low socioeconomic level are generally from crowded families with low income, with mother being housewife and father with occupations like worker or tradesman. There are not much occupation groups for these students to take example of or environment to gather information from. In this regard, studies for the low socioeconomic level students to receive more information on STEM careers can be performed when giving occupational consultancy services in schools. In addition, these students have limited financial means because they are located in crowded families. For this reason, they prefer to have their financial freedoms as soon as possible and do not want to take time for education. While providing occupational consultancy services in these schools, open education related to STEM career opportunities can also be offered.

The results of the performed research can be used as a resource in the studies to be performed regarding STEM careers. In the research, it is determined that there is a difference between the STEM career preference ratios of the students in low and upper socioeconomic levels. In this regard, studies can be performed in different education levels with larger universes and samples. Researches can be conducted where the factors affecting the STEM career preferences of the students in different socioeconomic levels are examined. Thus, the findings of this research are justified and can guide the consultancy activities.

The purpose in the recommendations given in the research is of course not to direct all the students to a STEM career. The goal in this research and its recommendations is to research the current condition related to the students that will make a career preference and to propose recommendations for the students to have more accurate information regarding the STEM careers and to make more conscious preferences.

\section{References}

Akbayir, K. (2002). Öğretmenlik mesleğine yönelmede ailenin ve branş seçiminde cinsiyetin rolü. V. Ulusal Fen Bilimleri ve Matematik Ĕ̈itimi Kongresi, 1183-1188.

Akgunduz, D. (2016). Yeni nesil okulda teknoloji entegrasyonu. In M. Yavuz (Ed.), Yeni Nesil Okul "Araştıran Okul” (pp. 133-185). Konya: Eğitim Yayınevi.

Altay Kose, T., \& Yangin, S. (2015). İlkokul ve ortaokul öğrencilerinin bilimsel kariyer ilgileri. Recep Tayyip Erdoğan Üniversitesi Sosyal Bilimler Dergisi, 1(1).

ATC21S (n.d.). Retrieved from http://www.atc21s.org

Aydeniz, M. (2017). Eğitim sistemimiz ve 21. yüzyll hayalimiz: 2045 hedeflerine ilerlerken, Türkiye için STEM odaklı ekonomik bir yol haritası. University of Tennessee, Knoxville.

Bahar, H. H. (2002). Eğitim fakültesi, tıp fakültesi ve iktisadi ve idari bilimler fakültesi 
öğrencilerinin bazı sosyo-ekonomik özellikleri ile fakülte tercihleri arasındaki ilişki. Erzincan Üniversitesi Ë̆itim Fakültesi Dergisi, 4(1), 125-144.

Bakhshi, H., Downing, J. M., Osborne, M. A., \& Schneider, P. (2017). The future of skills: Employment in 2030. London: Pearson and Nesta.

Balci, A. (2011). Sosyal bilimlerde araştırma: Yöntem, teknik ve ilkeler. Ankara: Pegem Akademi.

Batur, H. Z., \& Adiguzel, O. (2014). Schein'in kariyer değerleri perspektifinde öğrencilerin kariyer tercihlerini etkileyen faktörler üzerine bir araştırma: Isparta ili fen lisesi öğrencileri örneği. Dumlupınar Üniversitesi Sosyal Bilimler Dergisi, 42.

Beers, S. Z. (n.d.). 21st Century Skills: Preparing Students for THEIR Future.

Bursal, M., Buldur, S., \& Dede, Y. (2015). Alt sosyo-ekonomik düzeyli ilköğretim öğrencilerinin 4-8. sınıflar fen ve matematik ders başarıları: Cinsiyet perspektifi. Eğitim ve Bilim, 40(179). https://doi.org/10.15390/EB.2015.2913

Cakirer Calbayram, N., \& Gonenc, I. M. (2017). Meslek tercihi yapacak erkek öğrencilerin ebelik hakkındaki görüşleri. Sürekli Tıp Ĕ̆itimi Dergisi, 26(1).

Carnevale, A. P., Smith, N., \& Melton, M. (n.d.). STEM: Science, technology, engineering, mathematics. Washington, D.C.: Georgetown University Center on Education and the Workforce.

Colakoglu, M. H., \& Gunay Gokben, A. (2017). Türkiye'de eğitim fakültelerinde FeTeMM (STEM) çalışmaları. Informal Ortamlarda Araştırmalar Dergisi, 2(2), 46-69.

EBSO. (2015). Sanayi 4.0 Uyum Sağlamayan Kaybedecek! Retrieved from http://www. inovasyon.org/pdf/EBSO.Sanayi-4.0_Raporu.Ekim.2015.pdf

Eldem, M. O. (2017). TMMOB EMO Ankara Subesi Haber Bulteni 2017/3 (Endüstri 4.0). Retrieved from http://www.emo.org.tr/ekler/09287020c96f18a_ek.pdf?dergi=1111

Eraslan Capan, B., \& Korkut Owen, F. (2017). Ortaöğretim öğrencilerinin yönelmeyi düşündükleri eğitim alanları ve kariyer psikolojik danışmanlığı. Elektronik Sosyal Bilimler Dergisi, 16(61), 551-568. https://doi.org/10.17755/esosder.304694

Ercan, H. (2011). Türkiye'de mesleki görünüm. Ankara: Uluslararası Çalışma Ofisi. Retrieved from http://www.undp.org/content/dam/turkey/docs/projectdocuments/PovRed/MDG_F_192 8/UNDP-TR-YEM_Mesleki\%20Gorunum_Basim_TR.pdf

Erkan, S. (2011). Farklı sosyoekonomik düzeydeki ilköğretim birinci sınıf öğrencilerinin okula hazır bulunuşluklarının incelenmesi. Hacettepe Üniversitesi Eğitim Fakültesi Dergisi, 40(40).

European Commission/EACEA/Eurydice. (2011). Avrupa'da fen eğitimi: Ulusal politikalar, uygulamalar ve araştırma. Education, Audiovisual and Culture Executive Agency.

Frey, T. (2011). The coming of the terabyters: Lifelogging for a living. The Futurist, 35-36. 


\section{Macrothink}

Genc, G., Kaya, A., \& Genc, M. (2007). İnönü Üniversitesi Tıp Fakültesi öğrencilerinin meslek seçimini etkiyen faktörler. İnönü Üniversitesi Eğitim Fakültesi Dergisi, 8(14), 49-63.

Griffin, P., \& Care, E. (2015). The ATC21S method. P. Griffin \& E. Care (Eds.), Assessment and Teaching of 21st Century Skills: Methods and Approach (pp. 3-33). Dordrecht: Springer. https://doi.org/10.1007/978-94-017-9395-7_1

Gulhan, F., \& Sahin, F. (2018). Niçin STEM eğitimi?: ortaokul 5. sınıf öğrencilerinin STEM alanlarındaki kariyer tercihlerinin incelenmesi. Journal of STEAM Education, 1(1), 1-23.

Hamamc1, Z., Bacanl1, F., \& Dogan, H. (2013). İlköğretim ortaöğretim ve üniversite öğrencilerinin mesleki ve eğitsel kararlarını etkileyen faktörlerin incelenmesi. Elektronik Sosyal Bilimler Dergisi, 12(44), 284-299.

ISKUR. (2017a). 2017 Yılı İşgücü Piyasası Araştırması-Mesleki, Bilimsel ve Teknik Faaliyetler Sektörü Raporu.

ISKUR. (2017b). 2017 Yılı İşü̈cü Piyasası Araştırması-Bilgi ve İletişim Sektörü Raporu.

Johnson, B., \& Christensen, L. (2014). Nicel, nitel ve karma araştırma. In S. B. Demir (Ed.), Deneysel Olmayan Nicel Araştırma (T. Öztürk, Çev.) (pp. 343-374). Ankara: Eğiten Kitap.

Kapucu, S., \& Bahcivan, E. (2016). Lise öğrencilerinin fizik öğrenme anlayışlarının cinsiyet, sosyoekonomik durum ve fizik başarıları açısından incelenmesi. Abant İzet Baysal Üniversitesi Ĕ̆itim Fakültesi Dergisi, 16(2), 494-511. https://doi.org/10.17240/aibuefd.2016. 16.2-5000194939

Karakus Kacmaz, F. (2014). Tercih edilen meslekler bağlamında prekarizasyon sürecinin insan kaynakları yapılanma sürecine etkileri. II İş Ve Meslek Danışmanlığı Kongresi, Antalya.

Kaya, R., Aslan, H., \& Gunal, H. (2013). Tarih öğretmen adaylarının bölümü tercih etme nedenleri ile bölümden beklentilerine ilişkin görüşleri (Atatürk üniversitesi örneği). TUHED-Türk Tarih Eğitimi Dergisi, 2(2), 1-31.

Kayseri Il Milli Egitim Mudurlugu. (2013). STEM projesi ile bilim adamları yetiştirilecek. Retrieved from http://kayseri.meb.gov.tr/stem/index.aspx

Kayseri Il Milli Egitim Mudurlugu. (2016). Kayseri Milli Eğitim İstatistikler: 2015-2016.

Kearney, C. (2016). Efforts to increase students' interest in pursuing mathematics, science and technology studies and careers. National measures taken by 30 countries-2015 Report. European Schoolnet, Brussels.

Koksal, K. (2016). Üniversite ve meslek tercihini etkileyen unsurlara yönelik bir alan araştırmas1. Kara Harp Okulu Bilim Dergisi, 26(2).

Korkut Owen, F., \& Eraslan Capan, B. (2017). Fen, teknoloji, matematik ve mühendislik alanlarını seçmeyi planlama: Meslek seçimine ilişkin inançlar. Hacettepe Üniversitesi Ĕgitim Fakültesi Dergisi. https://doi.org/10.16986/HUJE.2017032884 
Korkut Owen, F., \& Eraslan Capan, B. (2018). Ortaöğretim öğrencilerinin fen teknoloji matematik ve mühendislik alanlarını seçmeyi düşünme nedenleri. Yaşadıkça Eğitim Dergisi, 31(2), 23-40.

Korkut Owen, F., \& Mutlu, T. (2016). Türkiye'de fen bilimleri, teknoloji, mühendislik ve matematik alanlarının seçiminde cinsiyetler arası farklılıklar. Yaşadıkça Eğitim, 30(2), 53-72.

Korkut-Owen, F., Kepir, D. D., Ozdemir, S., Ulas, Ö., \& Yilmaz, O. (2012). Üniversite öğrencilerinin bölüm seçme nedenleri. Mersin Üniversitesi Eğitim Fakültesi Dergisi, 8(3).

Koyunlu Unlu, Z., Dokme, I., \& Unlu, V. (2016). Adaptation of the science, technology, engineering, and mathematics career interest survey (STEM-CIS) into Turkish. Eurasian Journal of Educational Research, 63, 21-36. https://doi.org/10.14689/ejer.2016.63.2

MEB EARGED. (2011). MEB 21. yüzyıl öğrenci profili. Ankara. Retrieved from https://www.meb.gov.tr/earged/earged/21.\%20yy_og_pro.pdf

MEB. (2016). STEM eğitimi raporu. Ankara. Retrieved from http://yegitek.meb.gov.tr/ STEM_Egitimi_Raporu.pdf

MEB. (2018). Fen bilimleri dersi öğretim programı (İlkokul ve ortaokul 3, 4, 5, 6, 7 ve 8. siniflar). Ankara.

MESS. (2017). Doğan Burda Dergi Yayıncılık (Vol. 54, p. 892). İşveren.

National Research Council. (2011). Successful k-12 STEM education: Identifying effective approaches in science, technology, engineering, and mathematics. Committee on Highly Successful Science Programs for K-12 Science Education. Board on Science Education and Board on Testingand Assessment, Division of Behavioral and Social Sciences and Education. Washington, DC: The National Academies Press.

Naturfagsenteret. (2017). Project Lily. Retrieved from https://www.naturfagsenteret.no/ c1515601/prosjekt/vis.html?tid=1519408

NCREL \& Metiri Group. (2003). enGauge 21st century skills: For 21st century learners. Retrieved from http://www.cwasd.k12.wi.us/highschl/newsfile1062_1.pdf

Noonan, R. (2017). STEM jobs: 2017 update (ESA Issue Brief \# 02-17). Office of the Chief Economist, Economics and Statistics Administration, U.S. Department of Commerce. Retrieved from http://www.esa.gov/reports/stem-jobs-2017-update

OECD. (2017). Türkiye-ülke notlart-bir bakışta ĕgitim 2017: OECD göstergeleri. Retrieved from http://www.oecd.org/education/skills-beyond-school/EAG2017CN-Turkey-Turkish.pdf

Ozer, H., \& Calmasur, G. (2012). Research of student's faculty preferences by a multinomial logit model (the case of Ataturk University). Selcuk Üniversitesi Sosyal Bilimler Enstitüsü Dergisi, 28, 147.

Ozsoy, G., Ozsoy, S., Ozkara, Y., \& Memis, A. D. (2010). Öğretmen adaylarının öğretmenlik mesleğini tercih etmelerinde etkili olan faktörler. İlkögretim Online, 9(3). 


\section{Macrothink}

P21. (2016). Framework for 21st century learning. Retrieved from http://www.p21.org/ storage/documents/docs/P21_framework_0816.pdf

Sarikaya, T., \& Khorshid, L. (2009). Üniversite öğrencilerinin meslek seçimini etkileyen etmenlerin incelenmesi: Üniversite öğrencilerinin meslek seçimi. Türk Eğitim Bilimleri Dergisi, 7(2), 393-423.

Sonmez, V., \& Alacapinar, F. G. (2011). Örneklendirilmiş bilimsel araştırma yöntemleri. Ankara: Anı Yayınc1lık.

STEM Learning. (n.d.). STEMNET. Retrieved from https://www.stem.org.uk/elibrary/ collection $/ 2910$

Talwar, R., \& Hancock, T. (2010). The shape of jobs to come: Possible new careers emerging from advances in science and technology (2010-2030). Fast Future Research, Final report, January.

TUBITAK. (2010). Ulusal bilim, teknoloji ve yenilik stratejisi: 2011-2016. Ankara. Retrieved from https://www.tubitak.gov.tr/tubitak_content_files/BTYPD/strateji_belgeleri/UBTYS_20 11-2016.pdf

TUIK. (2016). Hanehalkı kullanılabilir gelire göre sıralı birikimli yüzdelik gruplar ve hanehalkı tipine göre en yüksek yıllık hanehalkı kullanılabilir gelirler, 2006.

UKCES. (2014). Careers of the future background report. Retrieved from https://www.gov. uk/government/uploads/system/uploads/attachment_data/file/385238/cotf_final.pdf

Uzun, N., \& Saglam, N. (2005). Sosyo-ekonomik durumun çevre bilinci ve çevre akademik başarısı üzerine etkisi. Hacettepe Üniversitesi Eğitim Fakültesi Dergisi, 29(29).

Wagner, C. G. (2011). Emerging careers and how to create them. The Futurist, 30-33.

World Economic Forum. (2015). New vision for education: Unlocking the potential of technology. Geneva. Retrieved from http://www3.weforum.org/docs/WEFUSA_NewVision forEducation_Report2015.pdf

Yerdelen, S., Kahraman, N., \& Tas, Y. (2016). Low socioeconomic status students' STEM career interest in relation to gender, grade level, and STEM attitude. Journal of Turkish Science Education, 13, 59-74.

YOK. (2017). Ĕ̈itim ve öğretim alanları sinıflamasına göre lisans düzeyindeki öğrenci sayılarl, 2016-2017. Retrieved from https://istatistik.yok.gov.tr 


\section{Copyright Disclaimer}

Copyright for this article is retained by the author(s), with first publication rights granted to the journal.

This is an open-access article distributed under the terms and conditions of the Creative Commons Attribution license (http://creativecommons.org/licenses/by/3.0/). 